\title{
Maranao Ethnobiology of G'nda/Chives (Allium schoenoprasum)
}

\author{
${ }^{1}$ Intesar T.Aba-Conding, Annabella G. Villarino ${ }^{2}$ \\ ${ }^{1}$ Graduate School, Mindanao State University, Marawi City, Lanao del Sur \\ ${ }^{2}$ Department of Biology-College of Natural Science and Mathematics, Mindanao State University, Marawi City, \\ Lanao del Sur
}

\begin{abstract}
:
Allium schoenoprasum, commonly called chives or G'nda by the Maranaos, is a small bulbous perennial known for its culinary and ornamental utility. The herb can be easily grown in average, medium, well-drained soils in full sun to part shade and is a native to both the Old and the New World. The current study is an investigation on the Traditional Ethnobiological Knowledge (TEK) of Maranaos on the commonly used chives. Aimed at finding out the uses of Chives among Maranaos, ethnography design, participant observation and key informant interviews based on semi-structured questionnaires were then employed. A total of thirty five (35) respondents coming from MSU - Marawi City, and from the municipalities of Piagapo and Masiu, all in Lanao del Sur participated. Among the respondents, five (5) were traditional healers aged 60-90 years old and thirty (30) TEK knowledgeable woman aged 20-50 years old. There were 16.67\% female participants from MSU-Marawi, 50\% from municipalities of Piagapo and 33.33\% from Masiu. Findings of the study showed that Maranao traditional ethnobiological knowledge is very unique and that Maranaos believed that chives are more powerful than medical practitioners during childbirth. Healers would administer chives during labor of a parturating woman and even to thwart of spirits and to cure headaches. Respondents divulged that most Maranao woman when about to give birth prefers giving birth at home in the presence of chives and its associated rituals. Other findings showed that Maranaos have rich traditional knowledge using not only plants but also animals but this knowledge is yet to be documented. In view of the aforementioned findings, it is recommended that there shall be proper exploration, documentation and conservation of the traditional ethnobiological knowledge of the Maranaos
\end{abstract}

Keywords: TEK (Traditional Ethnobiological Knowledge) chives, Maranaos, parturition

\section{INTRODUCTION}

Ethnobiology is the systematic cross cultural study of how people learn, name, use, and organize knowledge about the biota around them (Casagrande, 1999). Ethnobiology as a discipline combines the intuitions, skills, and biases of both the anthropologist and the biologist, often in quite unequal mixtures (Berlin, 1992).All societies in various parts of the world interact and perceive with the biological world in different ways and have different traditions of environmental knowledge (https://umanitoba.ca/.../Encyclopedia\%20of\%20Religion\%20And\%20Nature\%20Trad). Health care providers must open lines of communication with traditional healers and with pregnant women themselves to maximize program success (Banda, 2007).

Effective living in a given place requires that the individual being able to understand the particulars of that environment, unfortunately many traditional societies have complex and subtle understandings of the places in which they live (Pitta et al., 1999). These days, traditional knowledge on ethnobiology is gradually lost and endangered because younger generation prohibit themselves to learn from their elders old fashion way (Popova, 2009). Elders have this problem on attrition wherein young members of tribes leaving and not returning to learn from their elders -there is no one left then to carry on the traditions. This is also truefor the Maranao community,wherein once the elders are gone, their knowledge on traditional ethnobiology goes with them in their grave. Hence, this is the reason why this study was conducted to recall and explore the use of G'nda (chives, Allium schoenoprasum) among Maranaos. This study furtherly aim to document the various purposes of the plant to the Maranao community. The results of this study hope to contribute and increase the level of awareness about these organism as well about the Maranao ethnobiology. And hopefully younger Maranaos will be able to appreciate the traditional ways of their elders. This study also hopes to provide reference material to ethnobiologist and medical professional who are interested in the Maranao ethnobotany. Anticipating that they 
will create official procedure regarding the conservation of the traditional ethnobiological knowledge. Finally it investigation hopes to provide deeper insight into exactly what has been lost in the name of progress and what stands to be regained.

\section{Statement of the Problem}

The study investigated the Traditional Ethnobiological Knowledge of the Maranao Community in Lanao del Sur on Chives. Covered by this investigation is the inquiry on the enthnobotanical concepts of the Maranaos on G'nda, the determination if such concepts are based on published standard scientific concepts, the documentation of the various utility of G'nda, and the educational implications of Maranao ethnobotany to the global scene.

\section{Significance of the Study}

The Maranao tribe of Lanao del Sur recognizes the importance of plants not only in the practice of Islam religion but in their daily natural undertakings like farming, the spirit world, and the cycles of nature. This study then hopes to record theutility of G'nda of the Maranao folks. For the medicinal utility of the plant, this study aims to provide consolidated information from the Maranao folks themselves on how to use G'nda and how the plant is prepared before use as medicine. These generated baseline information is a concrete step in the preservation of Indigenous Knowledge System (IKS) and traditional healthcare practices of the Maranao in Lanao del Sur and would open the doors for further pharmacological investigations in the future.

This survey of the Maranao ethnobiology of selected organisms could crop outcomes and awareness that are helpful to the Maranao people as well the ethnobiological world for conservation and upgrading of the Maranao information. This information may also be enriched or cultured through official instruction and may be used to increase their learning level with integrity. This will help the Maranao communityearn recognition and respect and lead to the promotion of their ethnobiological knowledge.

\section{A. Study Design}

\section{METHODS}

This study is a qualitative research, employing ethnography as a method. The techniques used were participant observation and informal key informant interviews using semi-structured questionnaires as an instrument.

\section{B. Study Subjects}

This is an ethnographic study of the ethnobotany of G'nda (chives, Allium schoenoprasum)

Chives has almost the same shape as onions, but has a longer stalk with the same color, it has a shape that is almost similar to a leek but with a smaller size. Allium schoenoprasum, is a bulb-forming herbaceous perennial plant, growing to $30-50 \mathrm{~cm}$ (12-20 inches) tall. The bulbs are slender and conical long, $2-3 \mathrm{~cm}$ long and $1 \mathrm{~cm}$ broad, and grow in dense clusters from the roots. The stems are hollow and tubular, up to $50 \mathrm{~cm}$ long and 2-3 $\mathrm{mm}$ across with a soft texture, although, prior to the emergence of a flower, they may appear stiffer than usual. The grass-like leaves, which is shorter than the stems, are also hollow and tubular. The flowers are pale purple, and star-shaped with six petals (https://en.wikipedia.org/wiki/Chives )(Fig. 1). 


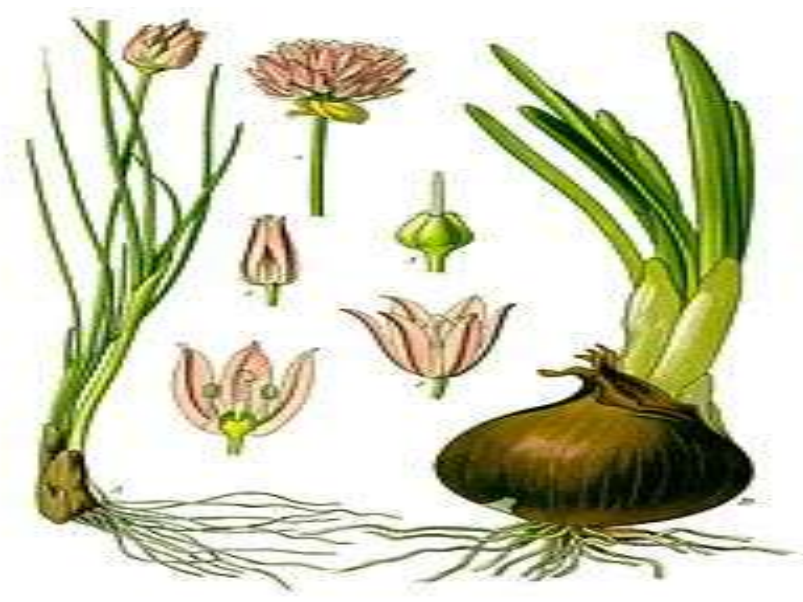

Figure 1. G'nda (Chives)

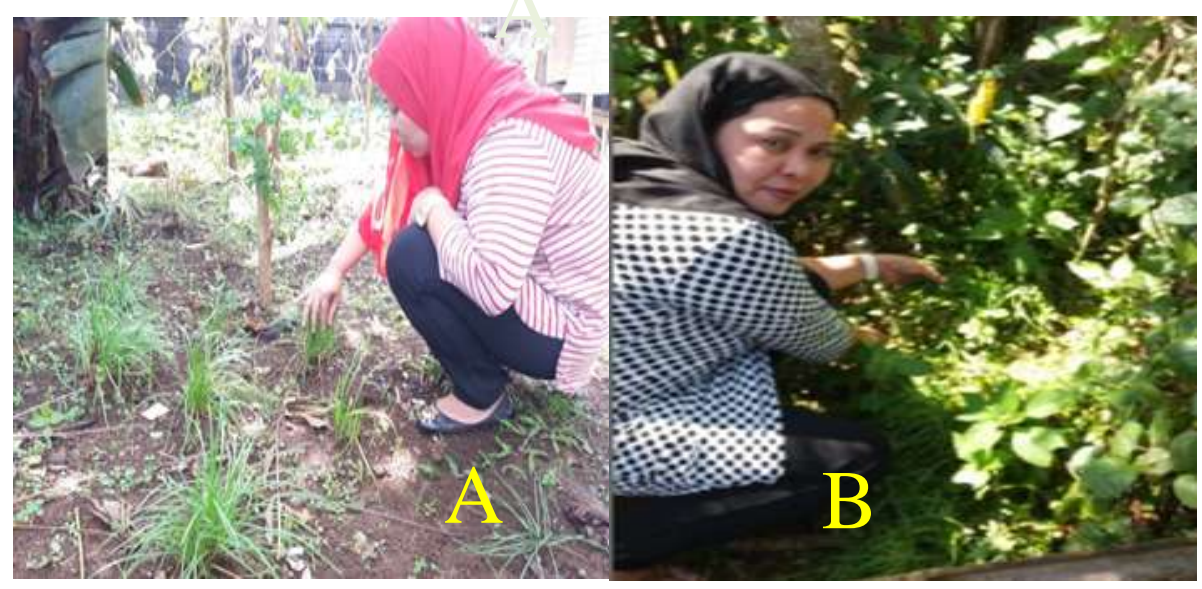

Figure 2. The transect walk in the municipalities of (A) Piagapo, and (B) Masiu, bothin Lanao del Sur, documenting the distribution of Chives plant.

C. Study Area

The study areas for this research were the communities of MSU - Marawi City, municipalities of Piagapo, and Masiu. Preliminary surveys and interviews revealed that majority of the Maranao traditional healers in the Province are from the said places.

The people living in the whole Lanao del Sur belong to the ethic group known as Maranao. Maranao means people of the lake, According to the early genealogical documents, they are referred to the native people living around the Lake Lanao. They are one of the main Islamic groups in the Philippines. The Maranao live in mostly the Lake Lanao area in the north-western sector of Mindanao, the Philippines, situated flanked by $7^{\circ} 30^{\prime}$ and $8^{\circ} 30^{\prime} \mathrm{N}$ and $124^{\circ} 00^{\prime}$ and $125^{\circ} 00^{\prime} \mathrm{E}$. The mercantile, cultural, and educational center of the Maranao is Marawi (formerly Dansalan), the capital of Lanao del Sur (Figure 3). 


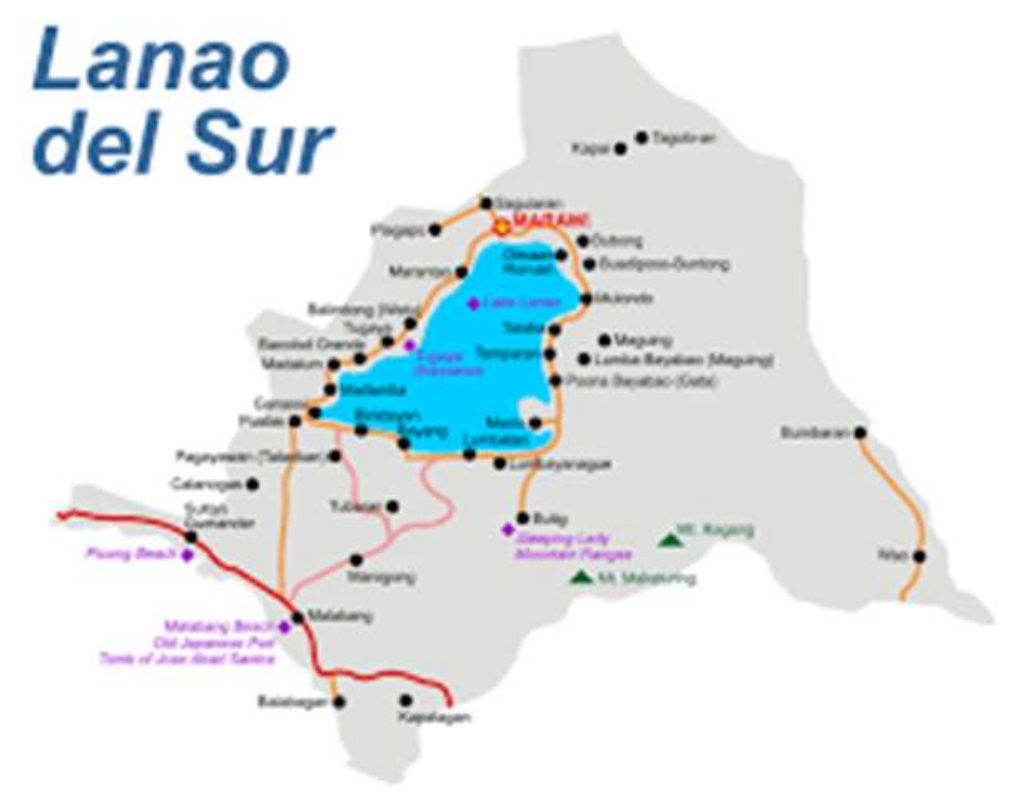

Figure 3. Map of Lanao del Sur showing the location of the respondent's municipalities.

D. Respondents of the Study

Thirty five (35) respondents were the source of the ethnobotany of G'nda in this study. Respondents include the five (5) traditional healers and thirty (30) TEK knowledgeable Maranao women and patients who gave birth under the supervision of traditional healers inhabiting MSU, Piagapo and Masiu, all in Lanao del Sur.

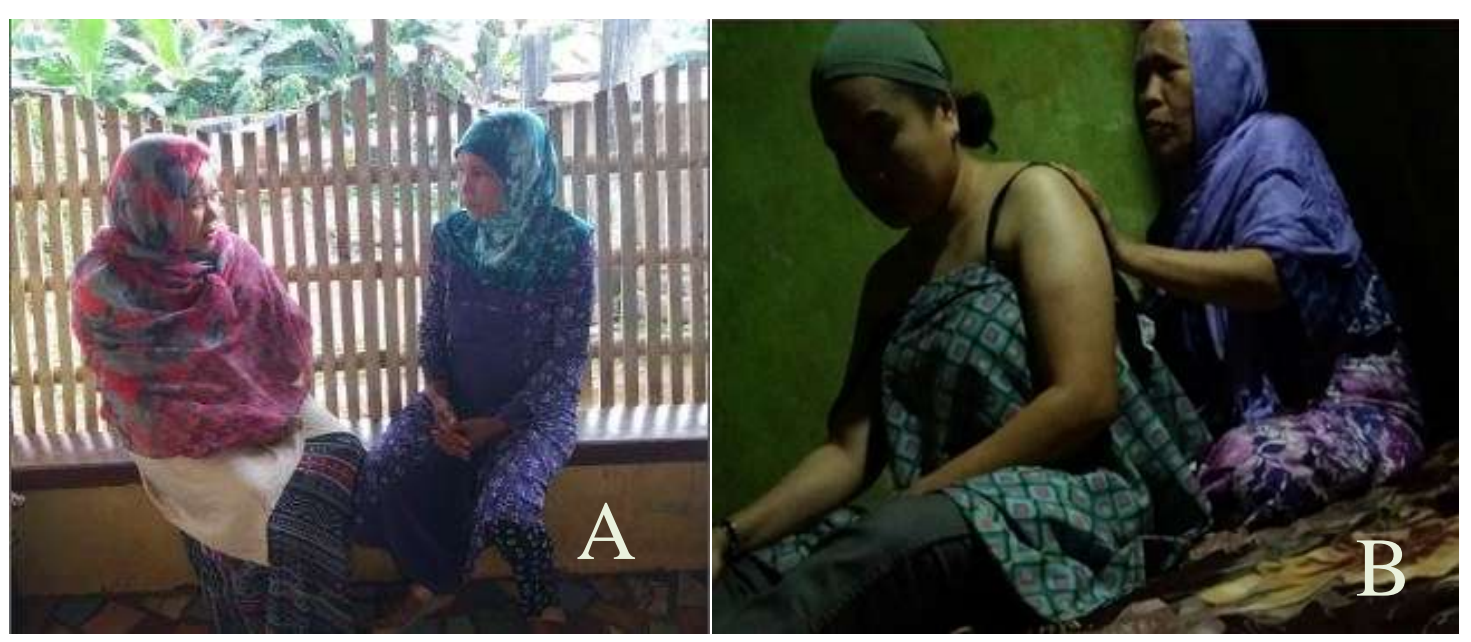




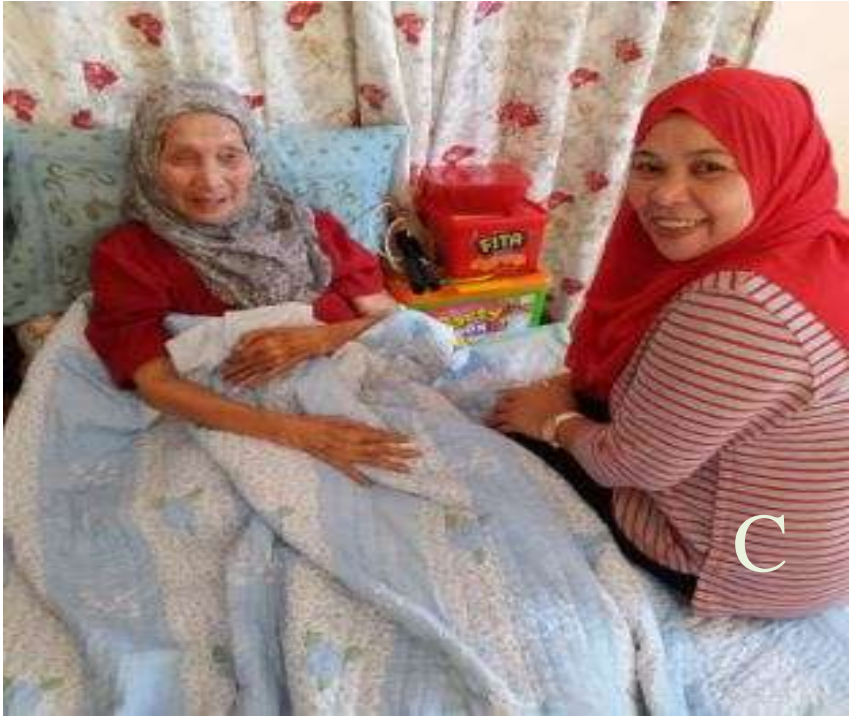

Figure 4. (A.) A woman patient who used chives and snake belt, according to her, it only took her 10-minutes to give birth, (B.)Traditional healer giving massage therapy (hilot) to a pregnant women and (C.) Interview with the oldest respondent Maranao traditional healer.

\section{E. Data Gathering}

Respondents were informed about the study details and given assurance about ethical principles, such as anonymity and confidentiality. This gives respondents some idea of what to expect from the interview , increases the likelihood of honesty and is also a fundamental aspect of the informed consent process. The researcher asked permission from the respondents/traditional healers together with his/her family to grant the following request for the conduct of this study. The schedules were arranged in such a way that the participants will make themselves available for the interview although some granted the interview right after asking permission. Upon the approval of the request, the researcher conducted her interview. Semi-structured interviews were used as a tool wherein several key questions were asked to define the subject to be explored, but would also allow the interviewer or interviewee to diverge in order to pursue an idea or response in a more detailed manner and provide participants with some guidance on what to talk about. The length of interviews varies depending on the response of the participant/informant. Medicinal uses and other uses of chives and snakes were carefully recorded. Interviews were carefully transcribed.

At the end of the semi-structured interviews, transect walk with the respondents was done to document the chives in the natural habitat of study sites.

\section{FINDINGS}

Maranao traditional healers were found to use traditional medicine that is based on indigenous theories, beliefs and experiences that are conserved and has been handed down from the past generations. It was also noted that during the conduct of this study, one healer was quite hesitant in sharing some of her knowledge in healing because she believed that once shared, its effect and power is lessen. Most of the respondents were mostly second generation of healers in their family, next to their parents who have already passed away. According to them, they believe that their healing craft is God-given

Among the five traditional healers and 30 TEK knowledgeable/acquainted people interviewed, $16.67 \%$ female participants were MSU- Marawi, 50\% from the municipality of Piagapo and $33.33 \%$ from Masiu. Ages of the respondents ranges from 60-90 years old. It was also noted that some respondents don't know their exact age because during their time, birth date was not recorded. Most respondents have not attended any formal schooling though some of them were able to read and write Arabic. Healers revealed their sentiment that no one from his/her family is interested to learn from their healing ability, one healer even said and I quote, " mamatay ako na dadn mataw sa kataw akn (if I die, no one knows my knowledge of healing)" Most of them grew up assisting their mother in terms of healing, in fact, in most cases, they are assisting when someone give birth. All (C) 2019, IJSMS 
of them were found to be users of G'nda. The uses of traditional and chemical practices are based upon the traditional practice of their parents who handed them the knowledge. Until now, it is still being used because it was tested and proven effective based on testimonies although to date, no study on the chemical constitution of G'nda/chives was made. Also, G'nda/chives was still used as spices for food. In times, they add this to scrambled eggs and for many times they cooked with other green leafy vegetables.

The interviewed healers divulged that chives were commonly used during parturition period, specifically to lessen labor pain and alsoto thwart bad spirits that might cause harm to both the mother and child. During child labor, the uterus contracts powerfully to facilitate the baby out, and those contractions are the primary source of labor pain. Women who give birth at home supervised by a traditional healer/midwife need something to lessen the pain. So traditional healers would prepare chive by squeezing the leaves and extracting the juice, and administered by allowing the pregnant woman to drink the juice. Synchronously, the healer also crushes the leaves then applies such topically on the tummy of the pregnant woman, to protect both the pregnant and the baby from the spirits. Maranaos believed that spirits are attracted to pregnant women and that negative spirits are very fond of pregnant women and their babies. According to the women patients who were applied with chives, they are used to chive, though the smell is sometimes unbearable. They are still fond of traditional antidotes, and that when they are pregnant, the practice of using traditional herbs alongside western medicine is common amongst Maranao pregnant women. These women further claimed that they would prefer indigenous health practices because of the need to prepare their womb against bad spirits, a practice that medical practitioners cannot provide. This finding agreed with Abraham(2002) who stated that Xhosa speaking women from Cape Town, South Africa follow indigenous healing practices for both themselves and their babies because of the require to "strengthen" the womb next to sorcery, to prevent childhood illness, and to treat and to treat indication they observe that biomedical services would not be able to treat. Abraham (2001) also suggests that considerably more attention needs to be given to the health care practices of pregnant women. Women were often unsatisfied with the treatment afforded by hospitals while giving birth, because aside from the expensive fees, their body parts will be exposed to medical practitioners. This explains why a lot of them still prefer giving birth at home. Also, Maranao women still chose birthing with the presence of traditional healers because aside from birthing at home, they can be surrounded by their family, like their mothers and husbands, where they feel safer. And the women can practice their beliefs and rituals. For them traditional medicines and rituals used are still the best during childbirth. Aside from birthing uses, chives are actually used by the healers in curing headaches. Such medication is prepared by pounding the leaves and then plastered on the forehead.

\section{CONCLUSION AND IMPLICATION OF THE STUDY}

This research revealed that most traditional healers are already too old with very low educational attainment thus their knowledge is endangered if not properly and timely documented. Findings of this study showed that Maranao traditional ethnobiological knowledge is very unique. G'nda or chives played a significant role in the lives of the Maranao people especially to those giving birth. It is further revealed that Maranao still believed on the effectivity of chives during parturition process even in the presence of medical practitioners. The views of Maranaowomen who have utilized the services of traditional healers before, during and or after pregnancy might be unacceptable for medical practitioner but Maranaos find such more workable.

Finally, results of this investigation can be used as basis by policy-makers in the formulation of ordinances and laws regarding the conservation of the traditional ethnobiological knowledge of the Maranaos and to increase awareness about this unique indigenous knowledge for the future generations and for further scientific research.

\section{References}

[1] Abrahams, N., Jewkes, R. and Mvo, Z. (2001), Health Care-Seeking Practices of Pregnant Women and the Role of the Midwife in Cape Town, South Africa. The Journal of Midwifery \& Women's Health, 46: 240-247. doi:10.1016/S1526-9523(01)00138-6

[2] Abrahams, N., Jewkes, R., \& Mvo, Z. (2002). Indigenous Healing Practices and Self-Medication amongst Pregnant Women in Cape Town, South Africa. African Journal of Reproductive Health / La Revue Africaine De La Santé Reproductive, 6(2), 79-86. doi: $10.2307 / 3583133$

[3] Allman, S. 1986. Childbearing and the training of traditional birth attendants in rural Haiti. Medical nthropologyNewsletter, 17(2): 4043. [CSA][Google Scholar]

[4] Asowa-Omorodion, F. I. 1997. Women's perceptions of the complications of pregnancy andchildbirth in two Esan communities, Edo State, Nigeria. Social Science and Medicine, 44(12): 1817-1824. 
[5] Bailey, P. E., Szászdi, J. A. and Glover, L. 2002. Obstetric complications: Does training traditional birth attendants make a difference?. Revista Panamericana de Salud Pública, 11(1): 15-23.

[6] Banda Y, Chapman V, Goldenberg RL, Stringer JSA, Culhane JF, Sinkala M, Vermund SH, Chi BH. Use of traditional medicine among pregnant women in Lusaka, Zambia. J Altern Complement Med. 2007;13(1):123-127.

[7] Barnes-Josiah, D., Myntti, C. and Augustin, A. 1998. The "Three Delays" as a framework for examining maternal mortality in Haiti. Social Science and Medicine, 46(8): 981-993.

[8] Berggren, G.G., Berggren, W., Verly, A., Garnier, N., Peterson, W., Ewbank, D. and Dieudonne, W.1983. Traditional midwives, tetanus immunization and infant mortality in rural Haiti. Tropical Doctor, 13: 79-87

[9] Berlin, B. (1992). On the Making of a Comparative Ethnobiology. In Ethnobiological Classification: Principles of Categorization of Plants and Animals in Traditional Societies (pp. 3-51). Princeton University Press. Retrieved from http://www.jstor.org/stable/j.ctt7ztq5q.4

[10] Brodwin, P. 1996. Medicine and morality in Haiti: The contest for healing power, Cambridge: Cambridge University Press

[11] Brodwin, P. 1997. Politics, practical logic, and primary health care in rural Haiti. MedicalAnthropology Quarterly, 11(1): 69-88.

[12] Carter, M. 2002. Husbands and maternal health matters in rural Guatemala: Wives' reports ontheir spouses' involvement in pregnancy and birth. Social Science and Medicine, 55: 437-450.

[13] Casagrande, D., Medin, D. \& Scott, A (Eds.). 1999,Ethnobiology Lives! Theory,Collaboration, and Possibilitiesfor the Study of Folk Biologies. Folkbiology . Cambridge, MA:MIT Press.

[14] “Chives". Retrieved February 19, 2018, from Wikipedia : https://en.wikipedia.org/wiki/Chives

[15] Jewkes, R., Abrahams, N. and Mvo, Z. (1998a). Study of the health care practices of pregnantwomen in Cape Town. Report 4. Summary of findings, conclusions and policy actions. Tygerberg: CERCA, Women's health. Medical Research Council. Available from: www.mrc.ac.za/gender/publications.htm. [Accessed 23 June 2003]

[16] Kaido, T.L., Veale, D.J.H. and Rama, D.B.K. (1997). Preliminary screening of plants used in South Africa as traditional herbal remedies during pregnancy and labour. J Ethnopharmacol 55: 185-191

[17] Kitzinger, J. (1995). Qualitative research: introducing focus groups. Br Med J 311: 299-302.

[18] Lorenz, D., Dent, P., \& Kauko, T. (Eds.). 1987. Value in a Changing Built Environment. John Wiley \& Sons,Inc. Hoboken, New Jersey, United States

[19] Pitta, D., Fung, H., Tsiang, Y. 1999. Ethical issues across cultures: managing the differing perspectives of China and the USA Maryland, USA JOURNAL OF CONSUMER MARKETING, VOL. 16 NO. 3, pp. 240-256

[20] Popova-Gosart, U (Ed.).(2009). Traditional Knowledge \& Indigenous Peoples. (C L'auravetl'an Information \& Education Network of Indigenous Peoples (LIENIP) and World Intellectual Property Organization (WIPO).

[21] World Health Organization (WHO). 1994. "Care for mother and baby at the health centre: Apractical guide". In Geneva: Department of Reproductive Health and Research WHO. 